CLINICAL STUDY

\title{
Subclinical hypothyroidism and dyslipidemia in children and adolescents with type 1 diabetes mellitus
}

\author{
Christian Denzer, Beate Karges ${ }^{1}$, Andrea Näke ${ }^{2}$, Joachim Rosenbauer ${ }^{3}$, Edith Schober ${ }^{4}$, Karl Otfried Schwab ${ }^{5}$, \\ Reinhard $\mathrm{W} \mathrm{Holl}^{6}$ for the DPV Initiative and the BMBF-Competence Network Diabetes Mellitus \\ Division of Pediatric Endocrinology and Diabetes, Department of Pediatrics and Adolescent Medicine, University Medical Center Ulm, Eythstrasse 24, \\ D-89075 Ulm, Germany, ${ }^{1}$ Division of Endocrinology and Diabetes, RWTH Aachen University, Aachen, Germany, ${ }^{2}$ Children's Hospital, University of \\ Dresden, Dresden, Germany, ${ }^{3}$ Institute of Biometrics and Epidemiology, German Diabetes Center, Leibniz Institute at Duesseldorf University, Duesseldorf, \\ Germany, ${ }^{4}$ Department of Pediatrics, Medical University of Vienna, Vienna, Austria, ${ }^{5}$ Department of Pediatrics and Adolescent Medicine, Freiburg \\ University Hospital, Freiburg, Germany and ${ }^{6}$ Institute of Epidemiology and Medical Biometry, Ulm University, Ulm, Germany \\ (Correspondence should be addressed to C Denzer; Email: christian.denzer@uniklinik-ulm.de)
}

\begin{abstract}
Objective: Recent epidemiological evidence suggests that subclinical hypothyroidism ( $\mathrm{SCH})$, defined as elevated TSH concentrations with normal circulating levels of triiodothyronine $\left(\mathrm{T}_{3}\right)$ and thyroxine $\left(\mathrm{T}_{4}\right)$, is associated with dyslipidemia and cardiovascular disease in adult populations. As currently no data are available on the prevalence of $\mathrm{SCH}$ and its potential association with lipoprotein profile in children and adolescents with type 1 diabetes (T1DM), we investigated the prevalence of SCH and associated lipid levels in young diabetic patients.

Design and methods: Cross-sectional analysis of 22747 children, adolescents, and young adults (age $<25$ years) with T1DM with normal $\mathrm{T}_{3}$ and $\mathrm{T}_{4}$ and either normal TSH $(\geq 0.5$ to $<4.0 \mathrm{mIU} / \mathrm{l}$, euthyroid group) or elevated TSH $(\geq 4.0$ to $<25.0 \mathrm{mIU} / \mathrm{l}$, SCH group) and simultaneous measurement of serum lipid and lipoprotein status.

Results: The prevalence rate of SCH in the study population was $7.2 \%$. Adjusted for age, gender, diabetes duration, current insulin dose, HbA1c, and BMI z-score, patients with SCH had significantly higher levels of total cholesterol (178.7 vs $175.3 \mathrm{mg} / \mathrm{dl}, P<0.001)$ and LDL-cholesterol (97.0 vs $93.7 \mathrm{mg} / \mathrm{dl}, P<0.001)$ compared with euthyroid patients.

Conclusions: $\mathrm{SCH}$ is a common finding in children, adolescents, and young adults with T1DM. SCH is associated with increased levels of total cholesterol, and LDL-cholesterol adjusted for potential confounders. SCH-associated increases in lipid and lipoprotein levels may therefore add to an increased long-term cardiovascular risk in young patients with T1DM.
\end{abstract}

European Journal of Endocrinology 168 601-608

\section{Introduction}

Subclinical hypothyroidism (SCH), defined as elevated TSH concentrations with normal circulating levels of triiodothyronine $\left(\mathrm{T}_{3}\right)$ and thyroxine $\left(\mathrm{T}_{4}\right)$, is a prevalent finding in adult populations with reported prevalence rates of up to $10 \%$ (reviewed in (1)). Epidemiological data on the prevalence of $\mathrm{SCH}$ in childhood and adolescence comes, however, mostly from smaller cohort studies in obese subjects. Reported prevalence rates of SCH in obese children range from 10 to $23 \%$, whereas in healthy, nonobese control populations, the prevalence of $\mathrm{SCH}$ is below 1\% (reviewed in (2)). Currently, there are no data available on the prevalence of SCH in young patients with type 1 diabetes (T1DM). Over the past years, there has been considerable controversy on the potential impact of $\mathrm{SCH}$ on the development of atherosclerosis and cardiovascular disease (reviewed in $(1,3)$ ). Very recently, a meta-analysis from the Thyroid Studies Collaboration provided unequivocal epidemiological evidence that SCH is associated with an increased risk of coronary heart disease and mortality (4). This increase in risk may be mediated by adverse changes in traditional (e.g. lipid profile) and emerging nontraditional cardiovascular risk factors (e.g., CRP and coagulation parameters) associated with $\mathrm{SCH}(1,3,5)$. As T1DM is associated with a sharply increased risk for cardiovascular disease in adulthood and high prevalence rates of cardiovascular risk factors have been demonstrated already in childhood and adolescence (6), early detection of potentially modifiable cardiovascular risk factors is essential for effective prevention of premature morbidity and mortality. The aim of this study was therefore to describe the prevalence rate of $\mathrm{SCH}$ in a large population of children, adolescents, and young adults with T1DM and to investigate the potential association of $\mathrm{SCH}$ with an adverse lipid profile. 


\section{Materials and methods}

\section{Study population}

Cross-sectional analysis examining the association of TSH serum level with serum lipids was performed in a large cohort of children, adolescents, and young adults with T1DM. Patients' data were extracted from the diabetes data acquisition system for prospective surveillance (DPV, Diabetessoftwaresystem zur prospektiven Verlaufsdokumentation) database. The electronic DPV system has been described in detail elsewhere $(7,8)$. In brief, since 1995, the DPV surveillance database continuously records demographic, anthropometric, and metabolic data obtained from patients treated for diabetes in participating centers from Germany and Austria. Anonymized longitudinal patient data are transmitted for central analysis twice yearly. Consistency of the data is reviewed in a standardized process, and inconsistent data are verified or corrected at the centers. For the present analysis, data from 45557 patients with T1DM for more than 3 months and a maximum age of 25 years were available. To be eligible for inclusion in the final study sample, the following criteria had to be fulfilled:

- simultaneous measurement of TSH and lipid status;

- $\mathrm{TSH} \geq 0.5$ and $<25.0 \mathrm{mIU} / \mathrm{l}$;

- normal values for total $\mathrm{T}_{4}\left(\mathrm{TT}_{4}, 76-152 \mathrm{nmol} / \mathrm{l}\right)$ or free $\mathrm{T}_{4}\left(\mathrm{FT}_{4}, 11.0-28.0 \mathrm{pmol} / \mathrm{l}\right)$, otherwise if not available normal values for total $\mathrm{T}_{3}\left(\mathrm{TT}_{3}, 1.3-\right.$ $3.3 \mathrm{nmol} / \mathrm{l})$, or free $\mathrm{T}_{3}\left(\mathrm{FT}_{3} 5.1-10.0 \mathrm{pmol} / \mathrm{l}\right)$ (simultaneous measurement with TSH mandatory in the $\mathrm{SCH}$ group (TSH $\geq 4.0 \mathrm{mIU} / \mathrm{l}$ );

- no ketoacidosis at the time of laboratory measurements ( $\mathrm{pH}>7.35)$;

- no replacement therapy with $\mathrm{L}-\mathrm{T}_{4}$ or iodine;

- no medication affecting thyroid function (glucocorticoids, propranolol, amiodarone, salicylates, phenytoin, phenobarbital, carbamazepine); and

- no lipid-lowering drugs.
In order to exclude patients with overt disorders of lipid metabolism (e.g. familiar hypercholesterolemia), the following cutoff levels for serum lipids were defined:

- total cholesterol $<300 \mathrm{mg} / \mathrm{dl}$

- LDL-cholesterol $<200 \mathrm{mg} / \mathrm{dl}$

- HDL-cholesterol $>20 \mathrm{mg} / \mathrm{dl}$.

Applying the described criteria to the available data set in March 2011 resulted in a final sample of 22747 patients with T1DM from 272 institutions (for a complete list of contributing centers, see Acknowledgements section). If more than one observation was available for a single patient, only the most recent observation was included in the analysis. A number of available observations for each investigated variable are given in Table 1. The most important reason for the exclusion of study subjects was a missing laboratory measurement of TSH and lipid status at the same time point. Other main reasons for exclusion were: use of $\mathrm{L}-\mathrm{T}_{4}$, iodine, and statins; age; and diabetes duration. Characteristics of the total population compared with the selected study population are detailed in Supplementary Table 1, see section on supplementary data given at the end of this article. Thyroid function was defined as euthyroid if TSH was $\geq 0.5$ and $<4.0 \mathrm{mIU} / \mathrm{l}$, and conversely, $\mathrm{SCH}$ was assumed if serum TSH was $\geq 4.0$ and $<25.0 \mathrm{mIU} / \mathrm{l}$.

\section{Laboratory parameters}

Measurements of TSH, peripheral thyroid hormones, and thyroid autoantibodies to thyroperoxidase (anti-TPO) and thyroglobulin (anti-TG) were performed locally at the participating centers using commercially available assays. Centers were advised to measure plasma concentrations of total cholesterol, LDL-cholesterol, HDL-cholesterol, and triglycerides after a 12-h fasting period. As previously described, fasting periods were not sufficiently met in all registered patients (6). Determination of total cholesterol, LDL-cholesterol, and HDL-cholesterol has been

Table 1 Anthropometric and laboratory characteristics of $n=22747$ patients with type 1 diabetes.

\begin{tabular}{|c|c|c|c|c|c|}
\hline & $n$ & Mean & S.D. & Median & Interquartile range \\
\hline Age (years) & 22747 & 13.71 & 4.25 & 14.27 & 6.02 \\
\hline Duration of diabetes (years) & 22747 & 5.72 & 3.92 & 4.96 & 5.57 \\
\hline BMI $z$-score & 22350 & 0.54 & 0.93 & 0.54 & 1.22 \\
\hline $\mathrm{HbA} 1 \mathrm{c}(\%)$ & 22353 & 8.06 & 1.66 & 7.77 & 1.85 \\
\hline TSH (mlúli) & 22747 & 2.24 & 1.45 & 1.94 & 1.34 \\
\hline $\mathrm{FT}_{4}(\mathrm{pmol} / \mathrm{l})$ & 12796 & 15.01 & 2.36 & 14.80 & 3.61 \\
\hline $\mathrm{TT}_{4}(\mathrm{nmol} / \mathrm{l})$ & 2412 & 101.63 & 17.48 & 97.91 & 24.46 \\
\hline $\mathrm{FT}_{3}(\mathrm{pmol} / \mathrm{l})$ & 2228 & 5.98 & 0.61 & 5.85 & 0.77 \\
\hline $\mathrm{TT}_{3}(\mathrm{nmol} / \mathrm{l})$ & 2952 & 1.89 & 0.58 & 1.70 & 0.75 \\
\hline Cholesterol (mg/dl) & 22416 & 175.30 & 33.12 & 172.0 & 42.0 \\
\hline LDL-cholesterol (mg/dl) & 16827 & 92.78 & 28.45 & 90.0 & 37.0 \\
\hline HDL-cholesterol (mg/dl) & 18132 & 62.15 & 15.61 & 61.0 & 19.0 \\
\hline
\end{tabular}

$\mathrm{FT}_{3}$, free triiodothyronine; $\mathrm{FT}_{4}$, free thyroxine; $\mathrm{TT}_{3}$, total triiodothyronine; $\mathrm{TT}_{4}$, total thyroxine. 
demonstrated to be only marginally influenced by food intake (9). As available data on triglyceride levels from the DPV database may not represent fasting levels and may be biased by food intake (10), triglycerides were excluded from the analysis. Total cholesterol was measured enzymatically, LDL-cholesterol was either calculated using Friedewald's formula or directly measured using a homogenous photometric procedure, and HDL-cholesterol was determined after dextran sulfate-magnesium precipitation. Values of locally determined $\mathrm{HbA} 1 \mathrm{c}$ as a measure of long-term metabolic control were standardized to the Diabetes Control and Complications Trial (DCCT) reference range (11).

\section{Anthropometric measurements}

Body weight and height were determined to the nearest $0.1 \mathrm{~kg}$ and $0.1 \mathrm{~cm}$ respectively using calibrated scales. Z-scores for height and BMI were calculated using the LMS method (12) based on German references (13). Duration of diabetes was calculated as the time difference between age at examination and the documented age at diabetes onset.

\section{Statistical analysis}

Statistical analysis was performed using the SAS software package version 9.2 (SAS Institute, Cary, NC,
USA). Data are presented as mean, s.D., median, and interquartile range. For analytical purposes, the study population was stratified into quartiles of TSH. Median differences of investigated parameters within TSH quartiles were assessed using the nonparametric Wilcoxon signed rank test and the Holm-Bonferroni method for multiple comparisons. Hierarchical linear modeling was used to perform multilevel analysis of predictors of serum lipid status (14). Denominator degrees of freedom were calculated according to Kenward-Roger, parameters were estimated using restricted partial likelihood, and iterations were optimized according to Newton-Raphson. Each model included the following set of predictor variables: SCH (categorical; $\mathrm{TSH} \geq 0.5$ to $<4.0 \mathrm{mIU} / \mathrm{l}$, $\mathrm{TSH} \geq 4.0$ to $<25.0 \mathrm{mIU} / \mathrm{l}$ ), gender (categorical), age group (categorical; $\leq 5$ years, $>5$ to $\leq 10$ years, $>10$ to $\leq 15$ years, $>15$ to $\leq 20$ years, $>20$ to $\leq 25$ years), diabetes duration (categorical; $\leq 2$ years, $>2$ to $\leq 5$ years, $>5$ to $\leq 10$ years, $>10$ years), BMI $z$-score (linear), current insulin dose (linear; IU/kg body weight), current HbA1c (linear), and diabetes center as random factor (random intercept model, covariance-structure Cholesky). Based on these models, differences in adjusted levels of the respective serum lipid concentrations between the euthyroid and the $\mathrm{SCH}$ group were assessed calculating least square means and two-tailed $t$-tests. $P$ values $<0.05$ were considered statistically significant (15).

Table 2 Mean and median values of TSH, cholesterol, LDL-cholesterol, HDL-cholesterol, and BMI z-score in the study population stratified into quartiles of TSH (q1-q4). $P$ values for median differences of investigated parameters within TSH quartiles calculated with Wilcoxon tests and the Holm-Bonferroni method for multiple comparisons.

\begin{tabular}{|c|c|c|c|c|c|c|}
\hline TSH q1-q4 & $n$ & Mean & S.D. & Median & $\begin{array}{c}\text { Interquartile } \\
\text { range }\end{array}$ & $\begin{array}{c}\text { P Holm- } \\
\text { Bonferroni }\end{array}$ \\
\hline \multicolumn{7}{|l|}{ TSH (mIU/l) } \\
\hline q1 & 5723 & 1.04 & 0.22 & 1.06 & 0.34 & \\
\hline q2 & 5652 & 1.66 & 0.16 & 1.67 & 0.28 & \\
\hline q3 & 5701 & 2.30 & 0.23 & 2.29 & 0.40 & \\
\hline $\mathrm{q} 4$ & 5671 & 3.96 & 1.87 & 3.45 & 1.14 & \\
\hline \multicolumn{7}{|c|}{ Cholesterol (mg/dl) } \\
\hline q1 & 5601 & 173.69 & 33.62 & 170.00 & 42.19 & $<0.001$ \\
\hline q2 & 5581 & 174.08 & 33.21 & 171.00 & 42.00 & \\
\hline q3 & 5615 & 175.57 & 32.55 & 173.00 & 40.00 & \\
\hline $\mathrm{q} 4$ & 5619 & 177.85 & 32.94 & 175.00 & 42.00 & \\
\hline \multicolumn{7}{|c|}{ LDL-cholesterol (mg/dl) } \\
\hline q1 & 4073 & 91.70 & 28.69 & 89.00 & 36.28 & $<0.001$ \\
\hline q2 & 4168 & 91.43 & 28.47 & 89.00 & 37.00 & \\
\hline q3 & 4279 & 93.00 & 28.04 & 90.10 & 36.74 & \\
\hline q4 & 4307 & 94.89 & 28.49 & 92.00 & 37.00 & \\
\hline \multicolumn{7}{|c|}{ HDL-cholesterol (mg/dl) } \\
\hline q1 & 4433 & 61.62 & 15.24 & 60.00 & 19.00 & 0.04 \\
\hline q2 & 4528 & 62.10 & 15.51 & 61.00 & 19.35 & \\
\hline q3 & 4573 & 62.30 & 15.48 & 61.00 & 19.00 & \\
\hline q4 & 4598 & 62.56 & 16.16 & 61.00 & 19.00 & \\
\hline \multicolumn{7}{|l|}{ BMI z-score } \\
\hline q1 & 5584 & 0.51 & 0.93 & 0.52 & 1.22 & 0.04 \\
\hline q2 & 5568 & 0.52 & 0.92 & 0.52 & 1.18 & \\
\hline q3 & 5608 & 0.55 & 0.93 & 0.55 & 1.21 & \\
\hline q4 & 5590 & 0.57 & 0.96 & 0.57 & 1.26 & \\
\hline
\end{tabular}




\section{Results}

Data sets from a total of 22747 children and adolescents (12 055 boys) were available for analysis. Anthropometric and metabolic characteristics of the study population are given in Table 1 . For a subset of 18431 subjects, data on thyroid autoantibody status were available, which was positive for either anti-TPO or anti-TG in 3562 children and adolescents (19.3\%). A total of 1638 children and adolescents with T1DM had SCH according to the definition applied, yielding a prevalence rate of $7.2 \%$.

Regrouping the study population by quartiles specific for TSH revealed stepwise increases in total cholesterol levels from TSH quartiles 1-4 and of LDL-cholesterol levels from TSH quartiles 2-4 respectively (Table 2). There was a trend for marginally higher HDL-cholesterol levels in the upper TSH quartiles, and mean BMI z-score also increased with increasing TSH level.

As described in the Materials and methods section, hierarchical linear modeling was performed to investigate differences in serum lipid and lipoprotein status between both groups accounting for potential confounders. Adjusted for the potentially confounding variables of age, gender, diabetes duration, diabetes center, insulin dose, $\mathrm{HbA1c}$, and BMI z-score, patients with elevated TSH had significantly higher total cholesterol and LDL-cholesterol (both $P<0.001$ ) (Table 3). Furthermore, mean BMI $z$-score was higher in the SCH group $(P<0.001)$, whereas there was no difference in mean height $z$-scores between the groups.

\section{Discussion}

This study provides evidence for an association of SCH with increased levels of serum lipids in a large population of children, adolescents, and young adults with T1DM. Of note, the reported associations of elevated TSH with total cholesterol and LDL-cholesterol remained after adjusting for confounding variables including BMI z-score, age, gender, diabetes duration, current insulin dose, HbAlc, and treating diabetes center. For the first time, our study reports the prevalence of $\mathrm{SCH}$ in a young population of patients with T1DM. The finding of a prevalence rate of $7.2 \%$ is in line with published prevalence rates of $\mathrm{SCH}$ in samples of nondiabetic adult populations (1). Of note, the here reported prevalence rate of $\mathrm{SCH}$ markedly exceeds the prevalence rate of $4.3 \%$ in the comparatively young and healthy NHANES III study population (16), which suggests that SCH represents a rather common disorder in children and adolescents with T1DM. The finding of an increased prevalence of SCH in our study population should be qualified by noting that given the epidemiological scale of the DPV database, which is covering $>80 \%$ of all patients with T1DM below the age of 25 years living in Germany and Austria (17), we decided to follow the proceedings of epidemiological reference studies reporting on prevalence rates of $\mathrm{SCH}$ and the potential association of SCH with dyslipidemia $(16,18,19,20)$ and rely on a single measurement of $\mathrm{TSH}$ and peripheral thyroid hormones for the diagnosis of SCH. Defined inclusion criteria aimed at excluding subjects with transient or secondary hyperthyrotropinemia (most importantly acute and chronic use of medication); however, only a timely second measurement of thyroid hormones could have safely excluded subjects with transient hyperthyrotropinemia (21).

T1DM is associated with increased cardiovascular disease risk factors already during childhood and adolescence (6). Besides poor glycemic control and hypertension, dyslipidemia and more specifically even mildly elevated levels of LDL-cholesterol may contribute significantly to the increased risk for premature cardiovascular disease and cardiovascular mortality in adult patients with T1DM (22).

Available data on the risk of cardiovascular disease in SCH remain in part controversial (reviewed in (1)), although published meta-analyses concluded that $\mathrm{SCH}$

Table 3 Anthropometric measures and laboratory data of euthyroid patients and patients with $\mathrm{SCH}$ adjusted for age, gender, diabetes duration, current insulin dose, HbA1c, BMI $z$-score, and treating diabetes center by hierarchical linear modeling. Presented figures are adjusted least square means, S.E.M.S, and $P$ values of $t$-tests for comparison between groups.

\begin{tabular}{|c|c|c|c|c|c|}
\hline & \multicolumn{2}{|c|}{ Euthyroid } & \multicolumn{2}{|c|}{$\mathrm{SCH}$} & \multirow[b]{3}{*}{$\boldsymbol{P}$} \\
\hline & \multicolumn{2}{|c|}{ TSH 0.5-4 mIU/l } & \multicolumn{2}{|c|}{ TSH 4-25 mlU/l } & \\
\hline & Mean & S.E.M. & Mean & S.E.M. & \\
\hline Cholesterol (mg/dl) & 175.3 & 0.41 & 178.7 & 0.86 & $<0.001$ \\
\hline LDL-cholesterol (mg/dl) & 93.7 & 0.66 & 97.0 & 0.99 & $<0.001$ \\
\hline HDL-cholesterol (mg/dl) & 62.2 & 0.24 & 62.6 & 0.46 & 0.428 \\
\hline BMI z-score & 0.53 & 0.01 & 0.59 & 0.02 & $<0.001$ \\
\hline Height $z$-score & 0.00 & 0.01 & -0.03 & 0.03 & 0.186 \\
\hline
\end{tabular}

$\mathrm{SCH}$, subclinical hypothyroidism. 
may be at least associated with a modestly increased risk for cardiovascular disease and mortality $(4,23,24)$. More recently, data from the population-based HUNT study (25) and reanalysis of the Wickham Survey cohort (26) revealed further support for the concept of a direct association of SCH with an increased incidence of ischemic coronary heart disease and mortality.

Thyroid hormone status has major effects on the cardiovascular system, and overt hypothyroidism leads to substantial alterations of traditional risk factors for cardiovascular disease including increased systemic vascular resistance and diastolic hypertension, decreased cardiac preload and impaired cardiac performance, increased coagulability, and as a hallmark feature elevated levels of total cholesterol and LDLcholesterol $(1,27)$. Therefore, the potential adverse effects of SCH on cardiovascular disease risk may well be mediated by alterations in traditional cardiovascular risk factors, of which increased total cholesterol and LDL-cholesterol levels have been most frequently reported to be associated with $\mathrm{SCH}$ across different study populations (3).

This study reports for the first time a positive association of $\mathrm{SCH}$ with increased total cholesterol and LDL-cholesterol in a very large at-risk population for cardiovascular disease of young patients with T1DM. Importantly, levels of serum lipids and lipoproteins in childhood and adolescence are related to age, gender, stage of pubertal development, and ethnicity of the subjects studied (28). Moreover, the association of SCH with dyslipidemia may be modified by insulin sensitivity (29). Therefore, we applied hierarchical linear modeling to account for the effects of potentially confounding variables including BMI $z$-score, gender, age group, diabetes duration, current insulin dose, and $\mathrm{HbA1c}$.

The magnitude of the observed differences in mean levels of serum lipids between the euthyroid and the SCH group of our study population is well in line with previous observations in middle- or older age nondiabetic populations, although reported differences in lipid patterns vary considerably according to applied definitions of SCH and demographic characteristics (1). The concept of mild thyroid failure represented by rising TSH levels as a risk factor for adverse serum lipid levels is further supported by our observation of increasing cholesterol and LDL-cholesterol levels with TSH quartiles and significantly highest levels of cholesterol and LDL-cholesterol in the highest TSH quartile.

Reference values for total cholesterol levels in children and adolescents are available from NCEP guidelines (30) and from the Lipid Research Clinic Pediatric Prevalence Study (31), which have been recommended by the American Academy of Pediatrics in a recent policy statement on 'Lipid screening and cardiovascular health in childhood' (28). Applying these references, mean total cholesterol in the SCH group ranges in the mid to upper limit of 'borderline' cholesterol levels, whereas total cholesterol in the euthyroid group is closer to the lower limit of the definition of 'borderline' cholesterol. Of note, mean cholesterol levels in both groups fall in the range of 'borderline' cholesterol.

The strength of this study is the large sample size of children, adolescents, and young adults with T1DM, representing a significant proportion of all T1DM patients in this age range living in Germany and Austria. Furthermore, the DPV database system provides detailed information on patients' characteristics allowing for careful correction of potential confounding factors in the analysis.

On the other hand, the cross-sectional design of our study does not allow any conclusions to be drawn about a causal relationship between elevated TSH and lipid levels, although small intervention studies with $\mathrm{T}_{4}$ supplementation support causality (32). Even more importantly, the impact of the observed differences in lipids in the SCH and the euthyroid group on prospective cardiovascular morbidity cannot be assessed directly from the study results. Furthermore, variations in applied assays for the determination of thyroid hormones and differences in fasting periods of study participants before blood sampling may have affected study results. In order to account for potentially confounding effects of methodical proceedings, treating diabetes center was included as a random factor in the analysis.

Currently, there are no data available on the association of $\mathrm{SCH}$ and cardiovascular disease from studies spanning the life period from childhood or adolescence into adulthood. Nonetheless, today it is well established that the process of developing atherosclerosis begins in childhood and the extent of atherosclerotic lesions in adulthood is associated with levels of traditional cardiovascular risk factors such as dyslipidemia and hypertension in early life (33, 34, 35). Evidence from the DCCT/EDIC study demonstrates that progression of carotid intima media thickness is associated with serum lipoprotein status in patients with T1DM (36).

\section{Conclusion}

In conclusion, this study's findings of borderline elevated levels of total cholesterol and LDL-cholesterol associated with SCH in children and adolescents with T1DM make it reasonable to suggest an additional increase of cardiovascular risk for affected patients. As SCH may especially affect cardiovascular morbidity and mortality in young adulthood (37), and elevated lipoprotein levels represent potentially modifiable risk factors, the reported high prevalence of $\mathrm{SCH}$ should warrant careful screening for thyroid dysfunction and associated mild dyslipidemia in an at-risk population of young patients with T1DM. 


\section{Supplementary data}

This is linked to the online version of the paper at http://dx.doi.org/10. 1530/EJE-12-0703.

\section{Declaration of interest}

The authors declare that there is no conflict of interest that could be perceived as prejudicing the impartiality of the research reported. Financial Disclosure: the authors have no financial relationships relevant to this article to disclose.

\section{Funding}

This work was supported by the Kompetenznetz Diabetes mellitus (Competence Network for Diabetes mellitus) funded by the German Federal Ministry of Education and Research (BMBF, FKZ 01GI0859).

\section{Author contribution statement}

C Denzer: Dr Denzer conceptualized the study, drafted the initial manuscript, and approved the final manuscript as submitted. B Karges: Dr Karges contributed to the study conception, critically reviewed and revised the manuscript, and approved the final manuscript as submitted. A Näke: Dr Näke critically reviewed and revised the manuscript and approved the final manuscript as submitted. J Rosenbauer: Dr Rosenbauer contributed to the statistical analyses, critically reviewed and revised the manuscript, and approved the final manuscript as submitted. E Schober: Dr Schober critically reviewed and revised the manuscript and approved the final manuscript as submitted. K Schwab: Dr Schwab contributed to the study conception, critically reviewed and revised the manuscript, and approved the final manuscript as submitted. R W Holl: Dr Holl supervised data collection, carried out statistical analyses, critically reviewed and revised the manuscript, and approved the final manuscript as submitted.

\section{Acknowledgements}

The DPV database system was supported by Novo Nordisk Germany, the Dr Bürger-Büsing Foundation, and the European Foundation for the Study of Diabetes (EFSD). We are indebted to all investigators participating in the DPV initiative. The following institutions contributed data to the present analysis: Aachen - Innere RWTH, Aachen - Uni-Kinderklinik RWTH, Aalen Kinderklinik, Ahlen St Franziskus Kinderklinik, Altötting-Burghausen Innere Medizin, Arnsberg-Hüsten Karolinenhosp. Kinderabteilung, Asbach Kamillus-Klinik Innere, Aue Helios Kinderklink, Augsburg Innere, Augsburg Kinderklinik Zentralklinikum, Aurich Kinderklinik, Bad Aibling Internist Praxis, Bad Hersfeld Kinderklinik, Bad Kösen Kinder-Rehaklinik, Bad Lauterberg Diabeteszentrum Innere, Bad Mergentheim - Diabetesfachklinik, Bad Mergentheim - Gemeinschaftspraxis DM-dorf Althausen, Bad Oeynhausen Herz-und Diabeteszentrum NRW, Bad Orb Spessart Klinik, Bad Salzungen Kinderklinik, Bad Waldsee Kinderarztpraxis, Bautzen Oberlausitz KK, Berchtesgaden CJD, Berchtesgaden MVZ Innere Med, Berlin DRK-Kliniken, Berlin Endokrinologikum, Berlin Kinderklinik Lindenhof, Sana Klinikum Lichtenberg, Berlin Klinik St Hedwig Innere, Berlin Virchow-Kinderklinik, Berlin Vivantes Hellersdorf Innere, Bielefeld Kinderklinik Gilead, Bocholt Kinderklinik, Bochum Universitätskinderklinik St Josef, Bonn Uni-Kinderklinik, Braunschweig Kinderarztpraxis, Bremen - Kinderklinik Nord, Bremen Kinderklinik St Jürgenstrasse, Bremerhaven Kinderklinik, Böblingen Kinderklinik, Celle Kinderklinik, Chemnitz Kinderklinik, ChemnitzHartmannsdorf Innere Medizin - DIAKOMED, Coesfeld Kinderklinik, Darmstadt Innere Medizin, Darmstadt Kinderklinik Prinz. Margaret, Datteln Vestische Kinderklinik, Deggendorf Kinderklinik, Deggendorf Medizinische Klinik II, Delmenhorst Kinderklinik, Detmold Kinderklinik, Dornbirn Kinderklinik, Dortmund Kinderklinik, Dortmund
Medizinische Kliniken Nord, Dresden Neustadt Kinderklinik, Dresden Uni-Kinderklinik, Duisburg Malteser St Anna Innere, Düren-Birkesdorf Kinderklinik, Düsseldorf Uni-Kinderklinik, Eberswalde Klinikum Barnim Werner Forßmann - Innere, Erfurt Kinderklinik, Erlangen Uni-Kinderklinik, Essen Elisabeth Kinderklinik, Essen Uni-Kinderklinik, Esslingen Klinik für Kinder und Jugendliche, Eutin Kinderklinik, Forchheim Diabeteszentrum SPP, Frankenthal Kinderarztpraxis, Frankfurt Diabeteszentrum Rhein-Main-Erwachsenendiabetologie (Bürgerhospital), Frankfurt Uni-Kinderklinik, Frankfurt Uni-Klinik Innere, Freiburg Uni Innere, Freiburg Uni-Kinderklinik, Friedberg Innere Klinik, Friedrichshafen Kinderklinik, Fulda Kinderklinik, Fürth Kinderklinik, Gaissach Fachklinik der Deutschen Rentenversicherung Bayern Süd, Garmisch-Partenkirchen Kinderklinik, Geislingen Klinik Helfenstein Innere, Gelnhausen Kinderklinik, Gelsenkirchen Kinderklinik Marienhospital, Gera Kinderklinik, Gießen Uni-Kinderklinik, Graz Universitäts-Kinderklinik, Göppingen Kinderklinik am Eichert, Görlitz Städtische Kinderklinik, Göttingen Uni-Kinderklinik, Güstrow Innere, Hachenburg Kinderpraxis, Hagen Kinderklinik, Halle UniKinderklinik, Halle-Dölau Städtische Kinderklinik, Hamburg Altonaer Kinderklinik, Hamburg Endokrinologikum, Hamburg Kinderklinik Wilhelmstift, Hamburg-Nord Kinder-MVZ, Hameln Kinderklinik, Hamm Kinderklinik, Hanau Kinderklinik, Hanau St Vincenz - Innere, Hannover Kinderklinik MHH, Hannover Kinderklinik auf der Bult, Haren Kinderarztpraxis, Heide Kinderklinik, Heidelberg Uni-Kinderklinik, Heidenheim Kinderklinik, Heilbronn Innere Klinik, Heilbronn Kinderklinik, Herdecke Kinderklinik, Herford Kinderarztpraxis, Herford Klinikum Kinder \& Jugendliche, Hermeskeil Kinderpraxis, Herten St Elisabeth Innere Medizin, Hildesheim Innere, Hildesheim Kinderarztpraxis, Hildesheim Klinikum Kinderklinik, Hinrichsegen-Bruckmühl Diabetikerjugendhaus, Hof Kinderklinik, Homburg Uni-Kinderklinik Saarland, Innsbruck Universitätskinderklinik, Itzehoe Kinderklinik, Jena Uni-Kinderklinik, Kaiserslautern Kinderarztpraxis Dr Geist, Kaiserslautern-Westpfalzklinikum Kinderklinik, Karlsburg Klinik für Diabetes \& Stoffwechsel, Karlsruhe Städtische Kinderklinik, Kassel Kinderklinik Park Schönfeld, Kassel Städtische Kinderklinik, Kaufbeuren Innere Medizin. Kempen Heilig Geist Innere, Kiel Städtische Kinderklinik, Kiel Universitäts-Kinderklinik, Kirchen DRK Klinikum Westerwald, Kinderklinik, Kirchheim-Nürtingen Innere, Kleve Innere Medizin, Koblenz Kemperhof 1. Med. Klinik, Koblenz Kinderklinik Kemperhof, Konstanz Innere Klinik, Konstanz Kinderklinik, Krefeld Innere Klinik, Krefeld Kinderklinik, Köln Kinderklinik Amsterdamerstrasse, Köln Uni-Kinderklinik, Landshut Kinderklink, Leipzig Uni-Kinderklinik, Leoben LKH Kinderklinik, Leverkusen Kinderklinik, Limburg Innere Medizin, Lindenfels Luisenkrankenhaus Innere, Lingen Kinderklinik St Bonifatius, Linz Innere Medizin, Linz Krankenhaus der Barmherzigen Schwestern, Abt. Kinder- und Jugendheilkunde, Lippstadt Evangelische Kinderklinik, Ludwigsburg Kinderklinik, Ludwigshafen Kinderklinik St AnnaStift, Lübeck Uni-Kinderklinik, Lübeck Uni-Klinik Innere Medizin, Lüdenscheid Kinderklinik, Magdeburg Städtisches Klinikum Innere, Magdeburg Uni-Kinderklinik, Mainz Uni-Kinderklinik, Mannheim Uni-Kinderklinik, Mannheim Uniklinik Innere Medizin, Marburg Uni-Kinderklinik, Marktredwitz Innere Medizin, Mechernich Kinderklinik, Memmingen Kinderklinik, Minden Kinderklinik, Moers Kinderklinik, Mutterstadt Kinderarztpraxis, Mönchengladbach Kinderklinik Rheydt Elisabethkrankenhaus, Mühlacker Enzkreiskliniken Innere, Mühldorf Gemeinschaftspraxis, München 3. Orden Kinderklinik, München Kinderarztpraxis Gavazzeni, München von Haunersche Kinderklinik, München-Gauting Kinderarztzentrum, MünchenHarlaching Kinderklinik, München-Schwabing Kinderklinik, Münster St Franziskus Kinderklinik, Münster Uni-Kinderklinik, Münster pädiat. Schwerpunktpraxis Ziegler, Nauen Havellandklinik, Neuburg Kinderklinik, Neunkirchen Marienhausklinik Kohlhof Kinderklinik, Neuss Lukaskrankenhaus Kinderklinik, Neuwied Kinderklinik Elisabeth, Nürnberg Cnopfsche Kinderklinik, Nürnberg Zentrum f Neugeb., Kinder \& Jugendl., Oberhausen Innere, Oberhausen Kinderklinik, Oberhausen Kinderpraxis Bachran, Offenbach/Main Innere Medizin, Offenbach/Main Kinderklinik, Offenburg Kinderklinik, Oldenburg Kinderklinik, Oldenburg Schwerpunktpraxis, Osnabrück Christliches Kinderhospital, Osterkappeln Innere, Ottobeuren Kreiskrankenhaus, Oy-Mittelberg Hochgebirgsklinik Kinder-Reha, Paderborn St Vincenz 
Kinderklinik, Papenburg Marienkrankenhaus Kinderklinik, Passau Kinderarztpraxis Handwerker, Passau Kinderklinik, Pforzheim Kinderklinik, Plauen Vogtlandklinikum, Prenzlau Krankenhaus Innere, Rastatt Gemeinschaftspraxis, Rastatt Kreiskrankenhaus Innere, Ravensburg Kinderklink St Nikolaus, Regensburg Kinderklinik St Hedwig, Remscheid Kinderklinik, Rendsburg Kinderklinik, Reutlingen Kinderarztpraxis, Reutlingen Kinderklinik, Reutlingen Klinikum Steinenberg Innere, Rheine Mathiasspital Kinderklinik, Rosenheim Innere Medizin, Rosenheim Kinderklinik, Rosenheim Schwerpunktpraxis, Rostock Uni-Kinderklinik, Rostock Universität Innere Medizin, Rotenburg/Wümme Kinderklinik, Rüsselsheim Kinderklinik, SaaldorfSurheim Diabetespraxis, Saalfeld Thüringenklinik Kinderklinik, Saarbrücken Kinderklinik Winterberg, Saarlouis Kinderklinik, Salzburg Kinderklinik, Scheidegg Reha-Kinderklinik Maximilian, Schw. Gmünd Stauferklinik Kinderklinik, Schweinfurt Kinderklinik, Schwerin Innere Medizin, Schwerin Kinderklinik, Schwäbisch Hall Diakonie Kinderklinik, Siegen Kinderklinik, Singen - Hegauklinik Kinderklinik, St Augustin Kinderklinik, St Pölten Kinderklinik, Stade Kinderklinik, Stolberg Kinderklinik, Stuttgart Olgahospital Kinderklinik, Suhl Kinderklinik, Sylt Rehaklinik, Tettnang Innere Medizin, Traunstein Praxis Drs Voll \& Belleville, Trier Kinderklinik der Borromäerinnen, Trostberg Innere, Tübingen Uni-Kinderklinik, Ulm Endokrinologikum, Ulm Uni-Kinderklinik, Vechta Kinderklinik, Viersen Kinderklinik, Villach Kinderklinik, Waiblingen Kinderklinik, Waldshut Kinderpraxis, Waldshut-Tiengen Kinderpraxis Biberbau, Weiden Kinderklinik, Weingarten Kinderarztpraxis, Wernberg-Köblitz SPP, Wien Preyersches Kinderspital, Wien SMZ Ost Donauspital, Wien Uni-Kinderklinik, Wiesbaden Horst-Schmidt-Kinderkliniken, Wiesbaden Kinderklinik DKD, Wilhelmshaven Reinhard-Nieter-Kinderklinik, Wilhelmshaven St Willehad Innere, Wittenberg Kinderklinik, Wolgast Innere Medizin, Worms Kinderklinik, Wuppertal Kinderklinik.

\section{References}

1 Biondi B \& Cooper DS. The clinical significance of subclinical thyroid dysfunction. Endocrine Reviews $2008 \quad 29 \quad 76-131$. (doi:10.1210/er.2006-0043)

2 Reinehr T. Thyroid function in the nutritionally obese child and adolescent. Current Opinion in Pediatrics 201123 415-420. (doi:10.1097/MOP.0b013e328344c393)

3 Duntas LH \& Wartofsky L. Cardiovascular risk and subclinical hypothyroidism: focus on lipids and new emerging risk factors. What is the evidence. Thyroid $2007 \mathbf{1 7} 1075-1084$ (doi:10.1089/thy.2007.0116)

4 Rodondi N, den Elzen WP, Bauer DC, Cappola AR, Razvi S, Walsh JP, Asvold BO, Iervasi G, Imaizumi M, Collet TH et al. Subclinical hypothyroidism and the risk of coronary heart disease and mortality. Journal of the American Medical Association 2010 304 1365-1374. (doi:10.1001/jama.2010.1361)

5 Paoli-Valeri M, Guzman M, Jimenez-Lopez V, Arias-Ferreira A, Briceno-Fernandez M \& Arata-Bellabarba G. Atherogenic lipid profile in children with subclinical hypothyroidism. Anales de Pediatría 200562 128-134. (doi:10.1157/13071309)

6 Schwab KO, Doerfer J, Hecker W, Grulich-Henn J, Wiemann D, Kordonouri O, Beyer P \& Holl RW. Spectrum and prevalence of atherogenic risk factors in 27,358 children, adolescents, and young adults with type 1 diabetes: cross-sectional data from the German diabetes documentation and quality management system (DPV). Diabetes Care 200629 218-225. (doi:10.2337/diacare.29. 02.06.dc05-0724)

7 Karges B, Kapellen T, Neu A, Hofer SE, Rohrer T, Rosenbauer J, Wolf J \& Holl RW. Long-acting insulin analogs and the risk of diabetic ketoacidosis in children and adolescents with type 1 diabetes: a prospective study of 10,682 patients from 271 institutions. Diabetes Care 201033 1031-1033. (doi:10.2337/ dc09-2249)

8 Grabert M, Schweiggert F \& Holl RW. A framework for diabetes documentation and quality management in Germany:
10 years of experience with DPV. Computer Methods and Programs in Biomedicine 200269 115-121. (doi:10.1016/S0169-2607 (02)00035-4)

9 Roche HM. Dietary carbohydrates and triacylglycerol metabolism. Proceedings of the Nutrition Society 199958 201-207. (doi:10.1079/PNS19990026)

10 Schwab KO, Doerfer J, Naeke A, Rohrer T, Wiemann D, Marg W, Hofer SE \& Holl RW. Influence of food intake, age, gender, $\mathrm{HbA1c}$, and BMI levels on plasma cholesterol in 29,979 children and adolescents with type 1 diabetes - reference data from the German diabetes documentation and quality management system (DPV). Pediatric Diabetes 200910 184-192. (doi:10.1111/ j.1399-5448.2008.00469.x)

11 The Diabetes Control and Complications Trial Research Group. The effect of intensive treatment of diabetes on the development and progression of long-term complications in insulin-dependent diabetes mellitus. New England Journal of Medicine 1993329 977-986. (doi:10.1056/NEJM199309303291401)

12 Cole TJ. The LMS method for constructing normalized growth standards. European Journal of Clinical Nutrition 1990 44 45-60.

13 Kromeyer-Hauschild K, Wabitsch M, Geller F, Ziegler A, Geiß HC, Hesse V, v Hippel V, Jaeger U, Johnsen D, Kiess W et al. Perzentilen für den Bodymass-Index für das Kindes- und Jugendalter unter Heranziehung verschiedener deutscher Stichproben. Monatsschrift Kinderheilkunde 2001149 807-818. (doi:10.1007/ s001120170107)

14 Shoukri MM \& Chaudhary MA. Analysis of correlated data with SAS and R. Boca Raton, FL: Chapman \& Hall/CRC Press, 2007.

15 Armitage P, Berry G \& Matthews JNS. Statistical Methods in Medical Research, 4th edn. Oxford: Blackwell Scientific, 2002.

16 Hollowell JG, Staehling NW, Flanders WD, Hannon WH, Gunter EW, Spencer CA \& Braverman LE. Serum TSH, T(4), and thyroid antibodies in the United States population (1988 to 1994): National Health and Nutrition Examination Survey (NHANES III). Journal of Clinical Endocrinology and Metabolism 2002 87 489-499. (doi:10.1210/jc.87.2.489)

17 Gerstl EM, Rabl W, Rosenbauer J, Grobe H, Hofer SE, Krause U \& Holl RW. Metabolic control as reflected by $\mathrm{HbA1c}$ in children, adolescents and young adults with type-1 diabetes mellitus: combined longitudinal analysis including 27,035 patients from 207 centers in Germany and Austria during the last decade. European Journal of Pediatrics 2008167 447-453. (doi:10.1007/ s00431-007-0586-9)

18 Hueston WJ \& Pearson WS. Subclinical hypothyroidism and the risk of hypercholesterolemia. Annals of Family Medicine 20042 351-355. (doi:10.1370/afm.79)

19 Tunbridge WM, Evered DC, Hall R, Appleton D, Brewis M, Clark F, Evans JG, Young E, Bird T \& Smith PA. The spectrum of thyroid disease in a community: the Whickham survey. Clinical Endocrinology 19777 481-493. (doi:10.1111/j.1365-2265.1977. tb01340.x)

20 Tunbridge WM, Evered DC, Hall R, Appleton D, Brewis M, Clark F, Evans JG, Young E, Bird T \& Smith PA. Lipid profiles and cardiovascular disease in the Whickham area with particular reference to thyroid failure. Clinical Endocrinology 1977 7 495-508. (doi:10.1111/j.1365-2265.1977.tb01341.x)

21 Garber JR, Cobin RH, Gharib H, Hennessey JV, Klein I, Mechanick JI, Pessah-Pollack R, Singer PA \& Woeber KA. Clinical Practice Guidelines for Hypothyroidism in Adults: Co-sponsored by American Association of Clinical Endocrinologists and the American Thyroid Association. Endocrine Practice $201218988-1028$.

22 Orchard TJ, Forrest KY, Kuller LH \& Becker DJ. Lipid and blood pressure treatment goals for type 1 diabetes: 10-year incidence data from the Pittsburgh Epidemiology of Diabetes Complications Study. Diabetes Care 200124 1053-1059. (doi:10.2337/diacare. 24.6.1053)

23 Rodondi N, Aujesky D, Vittinghoff E, Cornuz J \& Bauer DC. Subclinical hypothyroidism and the risk of coronary heart disease: a meta-analysis. American Journal of Medicine 2006119 541-551. (doi:10.1016/j.amjmed.2005.09.028) 
24 Ochs N, Auer R, Bauer DC, Nanchen D, Gussekloo J, Cornuz J \& Rodondi N. Meta-analysis: subclinical thyroid dysfunction and the risk for coronary heart disease and mortality. Annals of Internal Medicine 2008148 832-845.

25 Asvold BO, Bjoro T, Nilsen TI, Gunnell D \& Vatten LJ. Thyrotropin levels and risk of fatal coronary heart disease: the HUNT study. Archives of Internal Medicine $2008 \mathbf{1 6 8}$ 855-860. (doi:10.1001/ archinte.168.8.855)

26 Razvi S, Weaver JU, Vanderpump MP \& Pearce SH. The incidence of ischemic heart disease and mortality in people with subclinical hypothyroidism: reanalysis of the Whickham Survey cohort. Journal of Clinical Endocrinology and Metabolism 201095 1734-1740. (doi:10.1210/jc.2009-1749)

27 Cappola AR \& Ladenson PW. Hypothyroidism and atherosclerosis. Journal of Clinical Endocrinology and Metabolism 2003 88 2438-2444. (doi:10.1210/jc.2003-030398)

28 Daniels SR \& Greer FR. Lipid screening and cardiovascular health in childhood. Pediatrics 2008122 198-208. (doi:10.1542/peds. 2008-1349)

29 Bakker SJ, ter Maaten JC, Popp-Snijders C, Slaets JP, Heine RJ \& Gans RO. The relationship between thyrotropin and low density lipoprotein cholesterol is modified by insulin sensitivity in healthy euthyroid subjects. Journal of Clinical Endocrinology and Metabolism 200186 1206-1211. (doi:10.1210/jc.86.3.1206)

30 American Academy of Pediatrics. National Cholesterol Education Program: Report of the Expert Panel on Blood Cholesterol Levels in Children and Adolescents. Pediatrics 199289 525-584.

31 Tamir I, Heiss G, Glueck CJ. Christensen B, Kwiterovich P \& Rifkind BM. Lipid and lipoprotein distributions in white children ages 6-19 yr. The Lipid Research Clinics Program Prevalence Study. Journal of Chronic Diseases 198134 27-39. (doi:10.1016/ 0021-9681(81)90079-5)

32 Iqbal A, Jorde R \& Figenschau Y. Serum lipid levels in relation to serum thyroid-stimulating hormone and the effect of thyroxine treatment on serum lipid levels in subjects with subclinical hypothyroidism: the Tromso Study. Journal of Internal Medicine 2006260 53-61. (doi:10.1111/j.1365-2796.2006.01652.x)

33 Newman WP III, Freedman DS, Voors AW, Gard PD, Srinivasan SR, Cresanta JL, Williamson GD, Webber LS \& Berenson GS. Relation of serum lipoprotein levels and systolic blood pressure to early atherosclerosis. The Bogalusa Heart Study. New England Journal of Medicine 1986314 138-144. (doi:10. 1056/NEJM198601163140302)

34 Berenson GS, Srinivasan SR, Bao W, Newman WP III, Tracy RE \& Wattigney WA. Association between multiple cardiovascular risk factors and atherosclerosis in children and young adults. The Bogalusa Heart Study. New England Journal of Medicine 1998 338 1650-1656. (doi:10.1056/NEJM199806043382302)

35 Zieske AW, Malcom GT \& Strong JP. Natural history and risk factors of atherosclerosis in children and youth: the PDAY study. Pediatric Pathology \& Molecular Medicine 200221 213-237. (doi:10.1542/peds.2008-1349)

36 Nathan DM, Lachin J, Cleary P, Orchard T, Brillon DJ, Backlund JY, O'Leary DH \& Genuth S. Intensive diabetes therapy and carotid intima-media thickness in type 1 diabetes mellitus. New England Journal of Medicine $2003 \mathbf{3 4 8}$ 2294-2303. (doi:10.1056/ NEJMoa022314)

37 Kvetny J, Heldgaard PE, Bladbjerg EM \& Gram J. Subclinical hypothyroidism is associated with a low-grade inflammation, increased triglyceride levels and predicts cardiovascular disease in males below 50 years. Clinical Endocrinology $200461232-238$. (doi:10.1111/j.1365-2265.2004.02088.x)

Received 14 August 2012

Revised version received 29 January 2013

Accepted 4 February 2013 